\title{
Surficial and deep pore water circulation governs spatial and temporal scales of nutrient recycling in intertidal sand flat sediment
}

\author{
Markus Billerbeck ${ }^{1, *}$, Ursula Werner ${ }^{1}$, Lubos Polerecky ${ }^{1}$, Eva Walpersdorf ${ }^{2}$, \\ Dirk deBeer ${ }^{1}$, Markus Huettel ${ }^{3}$ \\ ${ }^{1}$ Max Planck Institute for Marine Microbiology, Celsiusstrasse 1, 28359 Bremen, Germany \\ ${ }^{2}$ Oceanlab, University of Aberdeen, Main Street, Newburgh, Aberdeenshire AB41 6AA, UK \\ ${ }^{3}$ Department of Oceanography, Florida State University, West Call Street, Tallahassee, Florida 32306-4320, USA
}

\begin{abstract}
This study addresses organic matter decomposition in permeable sediment of a sloping intertidal sand flat (German Wadden Sea) affected by current-induced pore water exchange and pore fluid drainage. Seasonal and spatial scales of aerobic and anaerobic mineralization were investigated at 2 sites, one near the water line and one on the upper flat. Hydrodynamic forcing during inundation caused deeper oxygen penetration through flushing of the uppermost sediment layer. This flushing resulted in higher areal oxygen consumption rates and lower depth integrated sulfate reduction rates in the submerged flat compared to the rates measured during exposure. Mineralization rates in the top $15 \mathrm{~cm}$ of the sediment were similar between both study sites and ranged from 38 (winter) to $280 \mathrm{mmol} \mathrm{C} \mathrm{m}{ }^{-2} \mathrm{~d}^{-1}$ (summer), with sulfate reduction contributing 3 to $25 \%$ to total mineralization, depending on the season. At the upper flat, these seasonal differences were reflected in the pore water concentrations of nutrients, dissolved inorganic carbon (DIC) and dissolved organic carbon (DOC). Near the low water line, however, pore water nutrient and DIC concentrations were independent of the season and up to 15 times higher compared to the values recorded in the upper flat. The differences in concentrations of metabolic products between the 2 sites resulted from a low tide drainage extending deep below the uppermost flushed layer and causing seepage of pore water near the low water line. Mineralization and nutrient release in these permeable intertidal sediments is affected by 2 circulation processes that work on distinctly different temporal and spatial scales: (1) rapid 'skin circulation' through the uppermost sediment layer during inundation that is characterized by short flow paths, low pore water residence time and immediate feedback to the ecosystem, and (2) slow 'body circulation' through deeper sediment layers during low tide that is characterized by long flow paths and pore water residence times, and acts as a buffered nutrient source to the ecosystem.
\end{abstract}

KEY WORDS: Intertidal flat - Permeable sediment - Oxygen consumption - Sulfate reduction · Sedimentary mineralization $\cdot$ Pore water transport

\section{INTRODUCTION}

Sandy sediments prevail in the intertidal regions of the German Wadden Sea (Flemming \& Ziegler 1995). Despite rather small bacterial numbers and low organic matter content of sandy sediments (Bergamaschi et al. 1997, Llobet-Brossa et al. 1998, Rusch et al. 2003), their high mineralization capacity has been recognized in recent studies (Cammen 1991, D'Andrea et al. 2002, Huettel et al. 2003). The permeability of the sand facilitates advective pore water transport through the upper sediment layers in contrast to muddy sediments, where diffusional processes dominate (Huettel \& Gust 1992, Huettel \& Webster 2001). The advective pore water transport can exceed diffusion by orders of magnitude (Lohse et al. 1996, Boudreau et al. 2001). 
During inundation of intertidal sand flats, the percolation of water through the sediment is driven by pressure gradients generated by the interaction of bottom currents with the sediment topography (Thibodeaux \& Boyle 1987, Glud et al. 1996) and by waves passing over the permeable bed (van der Loeff 1981, Precht \& Huettel 2003). This hydrodynamic forcing provides oxygen to the upper sediment layers and enhances aerobic mineralization of organic matter during inundation (Forster et al. 1996, Dauwe et al. 2001, Werner et al. 2006). The high aerobic mineralization in the upper sediment layers and anaerobic degradation processes deeper in the sediment are fuelled by the filtration of suspended particles and dissolved organic matter from the water column into the permeable bed (Huettel et al. 1996, Rusch et al. 2001). Furthermore, bioturbation and bioirrigation by benthic macrofauna add to the supply of electron acceptors and organic matter to the sediment (Graf \& Rosenberg 1997, Aller 2001). Inorganic nutrients, the products of mineralization, are removed from the sand by advective flushing (Huettel et al. 1998) thereby supporting primary production in the water column. The depth of the advective flushing is dependent on the permeability of the sediment and is usually restricted to the top few millimeters to centimeters of the sand bed (Brotas et al. 1990, de Beer et al. 2005). Within this surface layer of the tidal flat, organic matter can be recycled quickly and feedback may be provided to the ecosystem by the removal of the metabolic products from the sediment in a matter of hours to days.

The lack of advective flushing during low tide exposure of intertidal flats leads to the accumulation of metabolic products in the sediment (Rocha 1998, Kuwae et al. 2003). Transport, however, is not restricted to diffusion during exposure. Some benthic bioturbators are still active during exposure (Orvain \& Sauriau 2002). Also, pore water may be drained through the permeable sand driven by the buildup of a hydraulic gradient between the seawater level and the slower dropping pore water level (Nielsen 1990). The drainage mechanism transports pore water mainly laterally through the sediment towards the low water line, where pore water discharge can be observed also at the exposed sloping sediment surface constituting an important nutrient input to coastal waters (Howes \& Goehringer 1994, Jahnke et al. 2003, Billerbeck et al. 2006). Sediment layers extending deep below the regularly flushed upper layer can be affected by the drainage over horizontal distances between tens and hundreds of meters (Whiting \& Childers 1989, Jahnke et al. 2003, Billerbeck et al. 2006). Due to the long residence time and pathways of the pore water within these deeper layers of the intertidal flat, the feedback of mineralization products to the ecosystem is delayed.
This large body of the sand flat, thus, may act as a source of nutrients that can support primary production in the system during times of low nutrient concentrations in the seawater.

We hypothesize that, in an intertidal sand flat, 2 main pore water circulation patterns operate on distinctly different temporal and spatial scales, with implications for sedimentary mineralization and recycling of metabolic products: (1) The first pattern is a rapid 'skin circulation' during inundation within the top sediment layer, characterized by short flow paths and short residence times of pore water providing immediate feedback to the system. The advective supply of solutes and particles to the permeable sediment may enhance mineralization in the sediment surface layer. (2) The second pattern is a slower 'body circulation' during exposure of the tidal flat through the surface and deeper layers of the sediment with long flow paths and long pore water residence times. Due to the relatively long time interval between organic matter input and mineralization product release, this 'body circulation' may act as a buffer system for nutrients. In order to test these hypotheses, measurements of oxygen consumption and sulfate reduction were conducted on a sloping intertidal sand flat in the German Wadden Sea and combined with measurements of oxygen penetration depth and pore water concentrations of metabolic products. In order to assess the temporal scales of the mineralization processes, one study site near the low water line and one site at the upper flat were studied on a tidal and seasonal basis.

\section{MATERIALS AND METHODS}

Site description. Sampling and in situ measurements were carried out at the northeastern margin of the Janssand tidal flat $\left(53^{\circ} 44^{\prime} 07^{\prime \prime} \mathrm{N}, 007^{\circ} 41^{\prime} 57^{\prime \prime} \mathrm{E}\right)$, an $11 \mathrm{~km}^{2}$ intertidal sand flat located in the backbarrier area of the island of Spiekeroog, Wadden Sea, Germany (Fig. 1A). The margin zone of this tidal flat is sloping on average $1.6 \mathrm{~cm} \mathrm{~m}^{-1}$ towards the low water line (Fig. 1B). The tidal flat is covered by 1.5 to $2 \mathrm{~m}$ of water during high tide, and during low tide, the sand flat becomes exposed for approximately 6 to $8 \mathrm{~h}$, depending on tidal range. A 'lower sand flat' site close to the low water line and an 'upper sand flat' site approximately $45 \mathrm{~m}$ upslope the tidal flat (Fig. 1B) were chosen as the main study areas and investigated on a seasonal basis between December 2001 and March 2004 (Table 1). The lower flat site is inundated approximately 3 to $4 \mathrm{~h} \mathrm{~d}^{-1}$ longer than the upper flat.

Sediment characteristics. Grain size was analyzed by dry-sieving the top $10 \mathrm{~cm}$ of the sediment and classified according to Wentworth (1922). The porosity of 

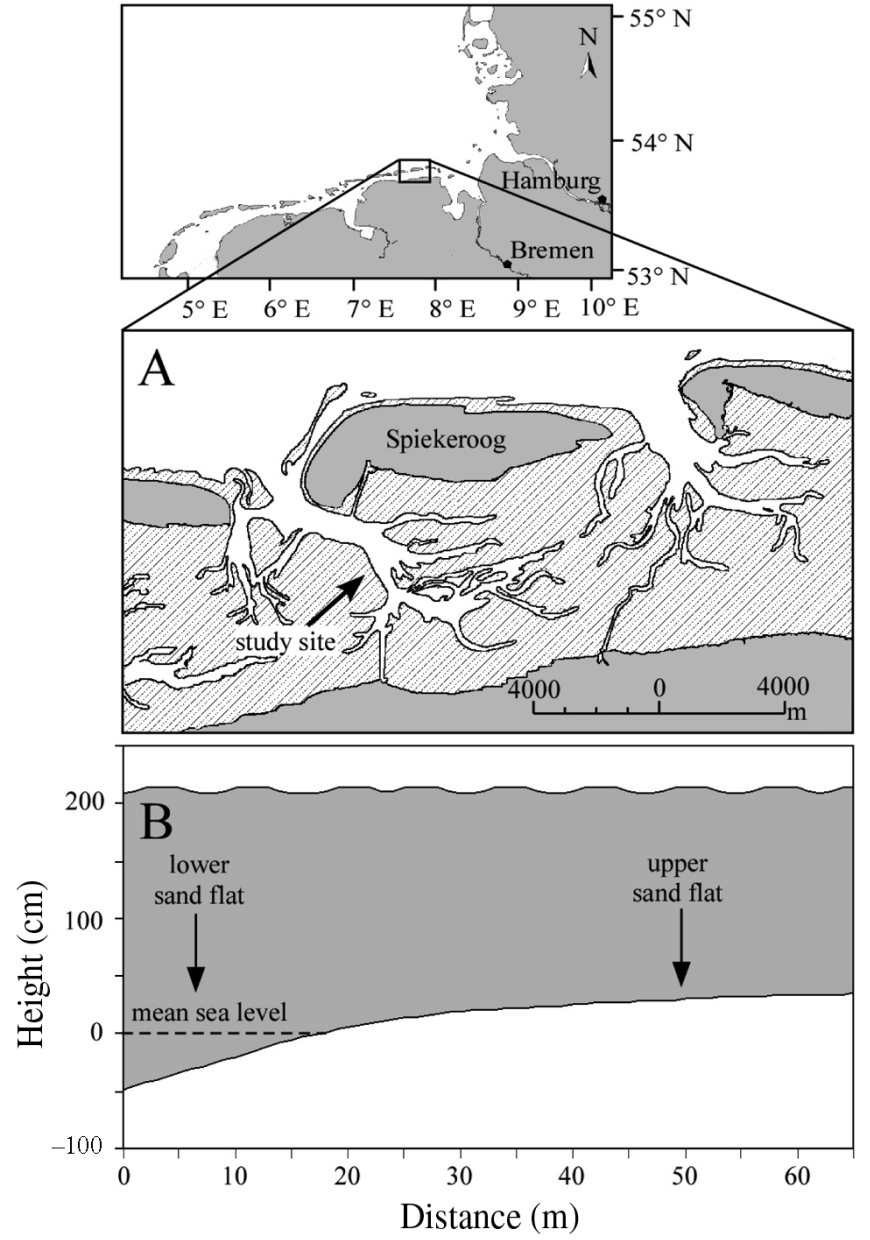

Fig. 1. (A) Study site near the island of Spiekeroog, Wadden Sea, Germany. (B) Tidal flat topography as surveyed during July 2003 relative to mean sea level

the top $15 \mathrm{~cm}$ of the sediment was determined in $1 \mathrm{~cm}$ intervals from the weight loss of a known volume of sediment after drying at $60^{\circ} \mathrm{C}$ until weight constancy was achieved. In July 2003, porosity of the top $10 \mathrm{~cm}$ of the sediment was measured every $2 \mathrm{~h}$ during exposure at the upper tidal flat. The permeability of the top $15 \mathrm{~cm}$ of the sediment was measured using the constant head method described in Klute \& Dirksen (1986). Sediment samples for total carbon (TC) and total inorganic carbon (TIC) measurements were sectioned into 0.5 to $1 \mathrm{~cm}$ intervals down to $10 \mathrm{~cm}$ depth and stored frozen. Prior to analysis, sediment samples were freeze-dried, ground and homogenized. Sample aliquots were then transferred into tin-cups for TC measurements and analysed with a Heraeus ${ }^{\circledR}$ CHNOrapid elemental analyzer using sulfanilamide as a calibration standard. TIC sample aliquots were measured by coulometric titration on a UIC ${ }^{\circledR}$ CM5012, and total organic carbon (TOC) was calculated by subtracting TIC from TC.
Pore water solutes. For pore water analysis (nutrients, dissolved inorganic carbon [DIC], dissolved organic carbon [DOC] and sulfate), 4 to 6 sediment cores were collected with a $36 \mathrm{~mm}$ core liner during low tide from the upper and lower sand flat sites. Additional sediment cores were collected over a tidal cycle from the upper sand flat site (20 min after inundation, high tide peak and low tide) between March and December 2002. The sediment cores were processed immediately after collection inside a glove box that was flushed with inert argon gas. Cores were sectioned to a depth of 10 to $20 \mathrm{~cm}(1 \mathrm{~cm}$ intervals to $10 \mathrm{~cm}$ depth, $2 \mathrm{~cm}$ intervals below), and sediment slices of the same depth were pooled to obtain a sufficient volume of pore water. The pooled sediment was transferred to a plastic Buechner funnel with a nylon mesh preventing loss of sediment through the funnel. The funnel with sediment was inserted into a pressure container such that the outflow end of the funnel protruded from lower end of the container. An inlet on the opposite side of the funnel permitted gas flow into the container. The pore water then was separated from the sediment matrix by flushing the pressure container for ca. $20 \mathrm{~s}$ with argon gas. In December 2001, pore water was sampled down to $15 \mathrm{~cm}$ sediment depth in $2.5 \mathrm{~cm}$ intervals with a pore water sipper as described in Huettel (1990). Pore water profiles were replicated 12 times at the upper flat and 6 times at the lower flat with the sipper. All pore water samples were passed through $0.2 \mu \mathrm{m}$ nylon syringe filters. Aliquots for DIC analysis were preserved with $20 \mu$ l of a saturated mercury chloride solution in $2 \mathrm{ml}$ Zinnser vials without headspace and kept refrigerated until further processing. Volumes of 3 to $5 \mathrm{ml}$ of pore water were transferred to precombusted glass vials for DOC analysis or into plastic vials for nutrient and sulfate measurements and kept frozen.

Pore water nutrients were measured spectrophotometrically with a Skalar Continuous-Flow-Analyzer according to Grasshoff et al. (1999). Pore water DIC was determined by flow injection analysis (Hall \& Aller 1992) with freshly prepared $\mathrm{NaHCO}_{3}$ calibration standards. For the analysis of DOC, total dissolved carbon and DIC were measured by high temperature catalytic oxidation on a Shimadzu ${ }^{\circledR}$ TOC-5050A analyzer using bicarbonate and phthalate as calibration standards. DOC concentration was obtained by subtraction of DIC from total dissolved carbon. Pore water sulfate concentration was determined with a Dionex ${ }^{\circledR}$ ion chromatograph using IonPac ${ }^{\circledR}$ AS9-HC analytical and IonPac ${ }^{\circledR}$ AG9-HC guard columns.

In situ sensor measurements. In situ measurements of oxygen penetration depth were performed by microsensors mounted on an autonomous profiler as described in Glud et al. (1999) and Wenzhöfer et al. 
(2000). Oxygen concentration was measured with Clark type oxygen microelectrodes (Revsbech 1989) with $300 \mu \mathrm{m}$ tip diameter, an actual sensing surface of $5 \mu \mathrm{m}$ and less than $5 \mathrm{~s}$ response time $\left(\mathrm{t}_{90}\right)$. The profiler was set up during low tide on the sediment with the microsensors initially positioned 1 to $2 \mathrm{~cm}$ above the sediment surface. Downward oxygen profiles were measured over at least one tidal cycle to a sediment depth of $6 \mathrm{~cm}$ in $1 \mathrm{~mm}$ intervals. Repeated profiles were measured every 20 to $60 \mathrm{~min}$. The oxygen sensors sometimes produced persistent holes in the sediment during low tide; such profiles were discarded from the data set.

Measurement of oxygen consumption rates (OCR). Volumetric OCRs were measured at in situ temperatures on freshly collected sediment cores in the laboratory. The sediment cores were percolated with aerated ambient seawater until oxygen was present in high concentrations at the desired measurement depth. After stopping the percolation, the decrease in oxygen concentration was monitored either with a Clark type oxygen microelectrode or a planar optode (de Beer et al. 2005, Polerecky et al. 2005) (Table 1). Consistency of both methods was demonstrated by Polerecky et al. (2005). The initial decrease in oxygen concentration was considered as the potential volumetric oxygen consumption rate (pOCR). Assessment of pOCR with the microsensor was carried out by positioning the sensor in the sediment core at defined depths at 2 to $5 \mathrm{~mm}$ intervals, and repetitively percolating water through the same core. The planar optode technique permitted the calculation of respiration rates with a resolution of $\approx 300 \mu \mathrm{m}$ over the optode area (ca. $25 \times 150 \mathrm{~mm}$; resulting oxygen image size $80 \times 480$ pixels). All measurements were performed on 2 replicate cores down to $8 \mathrm{~cm}$ sediment depth and in the dark to prevent photosynthesis.

Areal oxygen consumption rates (aOCR) were obtained by integrating the measured pOCR over the oxygen penetration depths measured in situ by the autonomous profiler and relating the result to surface area. As pOCR data were only available from June 2002, pOCR determined during December 2002 and March 2004 were combined with oxygen penetration depths measured in December 2001 and March 2002, respectively, to estimate areal OCR for the latter months. Areal oxygen consumption was estimated to be equal to total mineralization, assuming that reduced substances from anaerobic decay (e.g. sulfide from sulfate reduction) contributed to the measured oxygen consumption rates (Jørgensen 1982).

Potential (pSRR) and maximum/minimum sulfate reduction rates $\left(\mathbf{S R R}_{\max }\right.$ and $\left.\mathbf{S} \mathbf{R R}_{\min }\right)$. Sulfate reduction rates were measured in 2 to 3 replicate sediment cores with the tracer whole core incubation method

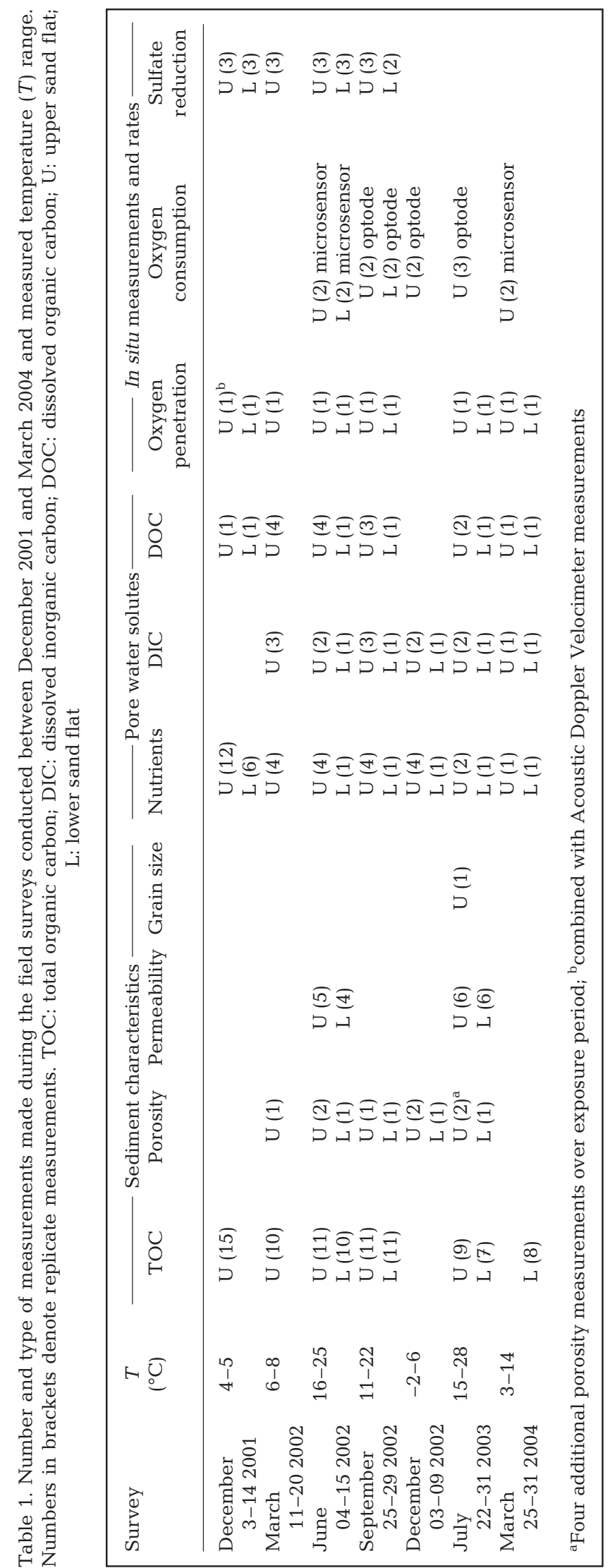


(Jørgensen 1978) modified for permeable sediments (de Beer et al. 2005) (Table 1). Radiolabeled ${ }^{35} \mathrm{SO}_{4}{ }^{2-}$ (Amersham $^{\mathrm{TM}}$ ) was added to $70 \mathrm{ml}$ of ambient seawater in the laboratory to obtain a specific activity of $340 \mathrm{MBq} \mathrm{mol}{ }^{-1} \mathrm{SO}_{4}{ }^{2-}$. The seawater-tracer solution was allowed to percolate into the sediment from the top of the core leading to a homogenous distribution of tracer within the permeable sand. After incubating the sediment at average in situ temperatures for 4 to $6 \mathrm{~h}$, the core was sliced into $1 \mathrm{~cm}$ sections and the incubation stopped by placing the slices into $20 \%$ ZnAc. The samples were processed with the cold chromium distillation procedure (Kallmeyer et al. 2004) that is based on the single step chromium reduction method (Fossing \& Jørgensen 1989). Radioactivity of ${ }^{35} \mathrm{SO}_{4}{ }^{2-}$ and Total Reduced Inorganic Sulfure (TRIS) was measured with a liquid scintillation counter (Packard ${ }^{\mathrm{TM}} 2500$ TR) using the Lumasafe Plus ${ }^{\circledR}$ scintillation cocktail. The calculation of sulfate reduction rates accounted for the measured porosities and pore water sulfate concentrations. Sediment horizons that are regularly supplied with oxygen by in situ advective transport can become anoxic during the stagnant incubation conditions and the measured sulfate reduction rates may, therefore, represent an overestimation of actual in situ rates. On the other hand, pore water flow conditions cannot be applied during the incubation due to the resulting relocation of the radiolabeled sulfides from their place of production. Hence, in situ sulfate reduction rates were estimated in a maximum/minimum scenario, with the maximum $\left(\mathrm{SRR}_{\max }\right)$ estimated by integrating $\mathrm{pSRR}$ over the entire measurement depth. The minimum $\left(\mathrm{SRR}_{\min }\right)$ was obtained by integrating pSRR only over the varying anoxic sediment depths down to $15 \mathrm{~cm}$, as inferred from the in situ oxygen penetration depths.

Measurement of near bottom flow velocities. Near bottom water flow was measured using a Nortek ${ }^{\mathrm{TM}}$ Acoustic Doppler Velocimeter (ADV) combined with the in situ determination of oxygen penetration depths in December 2001. The ADV measured 3 component flow velocities $(x, y, z)$ at a sampling frequency of $25 \mathrm{~Hz}$ within a cylindrical sampling volume (ca. $6 \mathrm{~mm}$ $\varnothing \times 6 \mathrm{~mm}$ ) located $100 \mathrm{~mm}$ below the probe. The ADV was mounted on a tripod with a profiling unit and flow velocities were measured stepwise for $30 \mathrm{~s}$ at $1 \mathrm{~cm}$ intervals from 1 to $25 \mathrm{~cm}$ above the sea floor over the inundation period. The average water current velocities were calculated for each height as the scalar of the 3 velocity vectors averaged over the 30 s measurement intervals.

Data analysis. Statistical analysis of differences between sampling sites and seasons were performed at a $95 \%$ confidence level ( $p<0.05)$. Pore water data as well as rates of oxygen consumption and sulfate reduc- tion were analyzed with the nonparametric MannWhitney $U$-Test for pairwise comparisons and the Kruskal-Wallis $H$-Test for between-group analysis. After detection of significance in the group analysis, the $\chi^{2}$ approach was used as a post hoc test to identify the significance between the populations. Linear regression analysis was performed at a 95\% confidence level for daily aOCR, $\mathrm{SRR}_{\min }$ and $\mathrm{SRR}_{\max }$ (dependent variables) against mean seasonal temperature (independent variable) as well as for oxygen penetration depth (dependent variable) against bottom flow velocity (independent variable).

\section{RESULTS}

\section{Sediment characteristics}

The Janssand tidal flat is characterized by well sorted $(\sigma<0.38$ phi) fine quartz sands with a mean grain size of $176 \mu \mathrm{m}$ (2.5 phi). With permeabilities ranging between 7.2 and $9.5 \times 10^{-12} \mathrm{~m}^{2}$ at the upper flat and between 0.5 and $3.1 \times 10^{-12} \mathrm{~m}^{2}$ at the lower flat; the sediment at both study sites permits advective pore water flows. The porosity of the top $15 \mathrm{~cm}$ of the sediment was 34.7 and $39.5 \%$ at the upper and lower flat sites, respectively. The porosity measurements taken at $2 \mathrm{~h}$ intervals in July 2003 showed that the porosity of the top $10 \mathrm{~cm}$ of the sediment remained almost constant during the entire exposure period (range between 36.4 and $38.6 \%$ ). A glassy sediment surface and visual observation of water runoff at the lower flat site during exposure indicated a discharge of draining pore water. This was not observed at the upper sand flat site, where the sediment surface had a 'dry' appearance during low tide. The sediment was organic poor during all seasons with mean TOC contents ranging between 0.04 and $0.11 \%$ at the upper flat and 0.06 and $0.13 \%$ at the lower flat. The sedimentary TOC content showed no seasonal trend at either study site.

\section{pOCR and pSRR}

The pOCR at the lower sand flat was similar to that measured at the upper flat during June and September 2002 (Fig. 2), except in a zone of higher pOCR activity that was detected between 0.8 and $1.6 \mathrm{~cm}$ sediment depth in June 2002 ( $p<0.001)$. During September 2002, mean pOCR were slightly lower at the lower sand flat site $(p<0.01)$ but very variable between cores in the top $\mathrm{cm}$ of sediment (Fig. 2). After a repeated flushing of the sediment core from the lower flat that exhibited highest $\mathrm{pOCR}$, the rates decreased considerably, suggesting that oxidation of reduced solutes or 


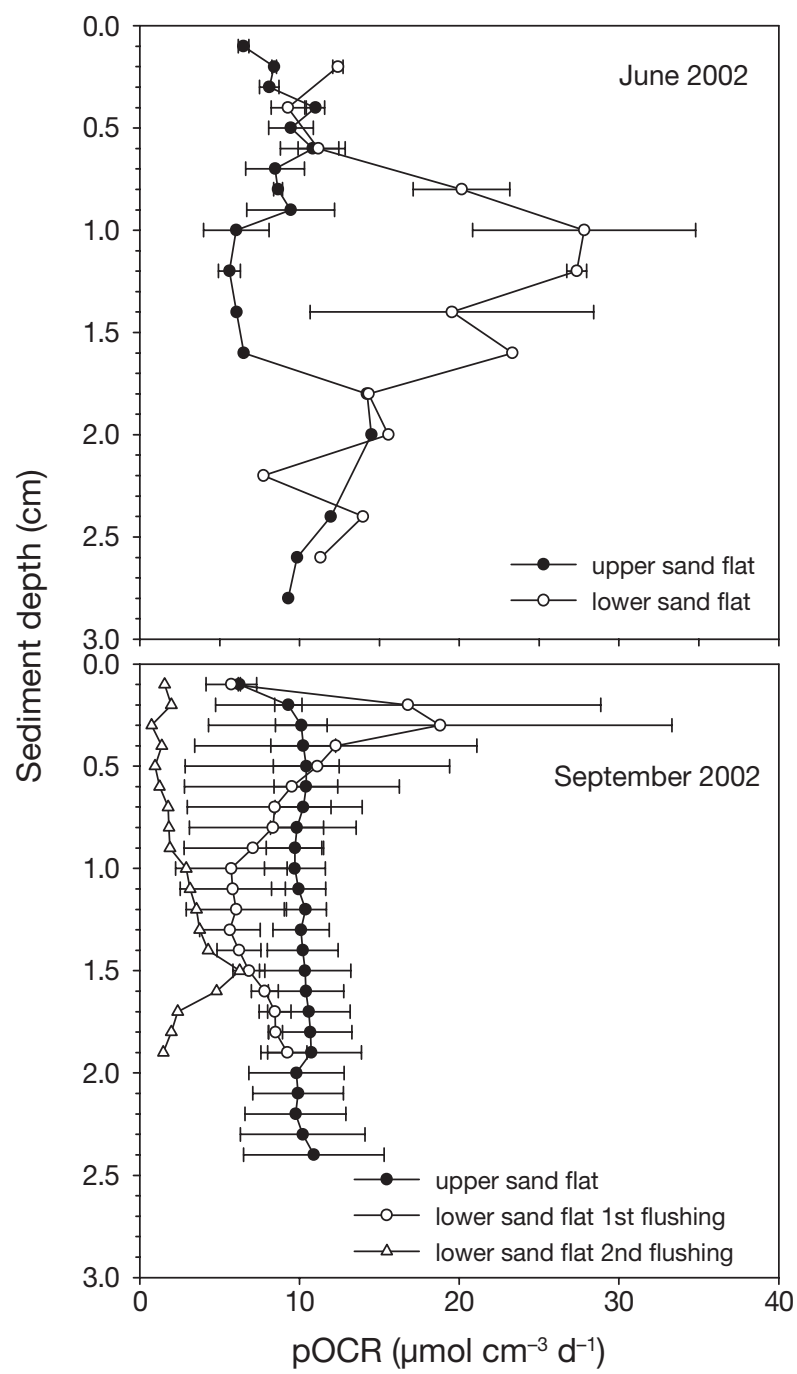

Fig. 2. Potential volumetric oxygen consumption rates (pOCR) at the upper and lower sand flats during June and September 2002. Rates are plotted as the mean of 2 cores with the range as error bars down to the maximum penetration depth of oxygen for the respective months. For clarity, only every third datapoint (every $1 \mathrm{~mm}$ ) is shown from the planar optode measurements in September

particle bound material largely contributed to the higher rates during the first measurement in September 2002. No reduction in pOCR in the regularly oxygenated sediment layer was observed during repeated measurements of sediment cores from the upper sand flat (Polerecky et al. 2005).

In the regularly oxygenated sediment layer down to the maximum oxygen penetration depth, the pOCR showed a clear seasonal trend at the upper sand flat (Fig. 3) with lower rates during the winter months (December, March) than during summer (June, September, July) ( $\mathrm{p}<0.001)$. While pOCR did not differ between June and September 2002, highest pOCR were measured during the extraordinarily warm July

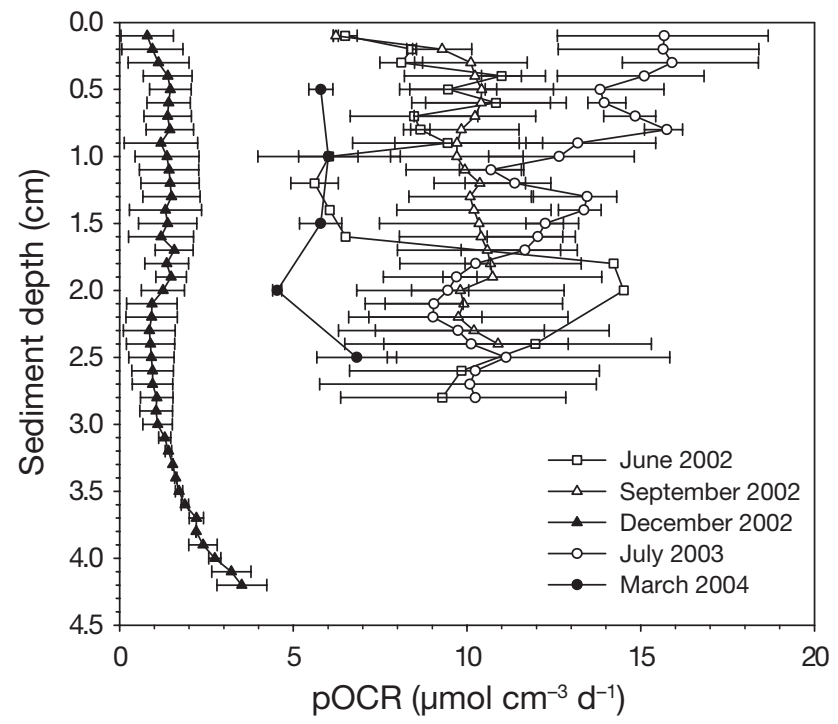

Fig. 3. Potential volumetric oxygen consumption rates (pOCR) at the upper sand flat between June 2002 and March 2004. All rates are plotted as the mean of 2 cores ( 3 cores in July 2003) with the range as error bars down to the maximum oxygen penetration depth for the respective months. For clarity, only every third datapoint (every $1 \mathrm{~mm}$ ) is shown from the planar optode measurements in September, December and July

in 2003. Below the maximum oxygen penetration depth, pOCR increased at both study sites during most months, but remained constant or decreased during September 2002 at the upper and lower flat sites, respectively (data not shown).

Similar to the pOCR measurements, site differences in pSRR were small between the upper and lower flat (Fig. 4). The pSRR rates were only marginally higher at the lower sand flat site $(p<0.05)$ during December 2001 and June 2002 and did not differ between the upper and lower flats during September 2002.

As compared to pOCR, the seasonal trend was less pronounced for pSRR (Fig. 4). Highest SRR were measured in September 2002 in 2 to $3 \mathrm{~cm}$ sediment depth at both study sites. Except for this zone of higher activity, no difference in pSRR was detected between September 2002, June 2002, and December 2001 for the upper and lower sand flat sites. Significantly lower potential of sulfate reduction was, however, measured at the upper sand flat during March 2002 ( $p<0.001)$. The highest potential of sulfate reduction was usually measured in sediment layers located near the maximum depth of oxygen penetration (Fig. 4). Below this zone of higher activity, pSRR decreased with sediment depth in most profiles.

\section{aOCR and depth-integrated $S R R_{\max }$ and $S R R_{\text {min }}$}

In situ aOCR and $\mathrm{SRR}_{\text {min }}$ were calculated from the measured potential rates (pOCR, pSRR) and in situ 


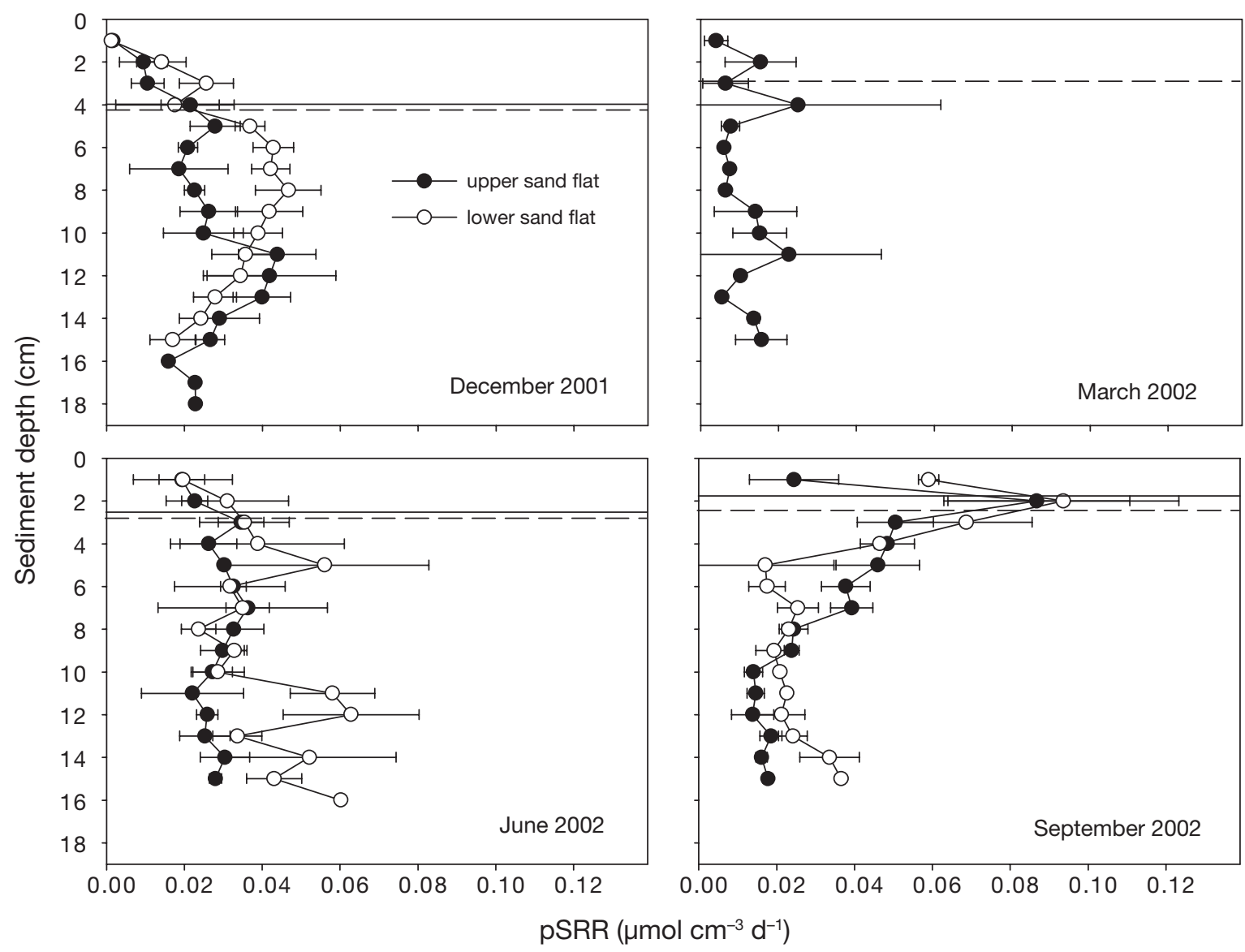

Fig. 4. Potential volumetric sulfate reduction rates (pSRR) at the upper and lower sand flat sites between December 2001 and September 2002 (March 2002 only upper flat). Mean and standard deviation (error bars) were calculated from 3 replicate cores. The maximum oxygen penetration depth is marked with dashed (upper flat) and solid (lower flat) lines

oxygen penetration depths, since oxygen can inhibit the activity of sulfate reducers (Marschall et al. 1993). The maximum value for depth-integrated $\mathrm{SRR}_{\max }$ is not corrected for oxygen penetration depth, as sulfate reduction activity has also been measured within the regularly oxygenated sediment layer (Jørgensen 1977 , Jørgensen \& Bak 1991).

Oxygen generally penetrated deeper into the sediment during inundation than during exposure of the tidal flat (Fig. 5). At the upper sand flat, the maximum penetration depth of oxygen into the sediment was $4.2 \mathrm{~cm}$ in December and varied between 2.4 and $2.8 \mathrm{~cm}$ for all other investigated months. Due to the deeper oxygen penetration, aOCR (Figs. 5 \& 6A) was significantly higher during inundation compared to exposure (at least $\mathrm{p}<0.05$ ). Areal OCR followed a seasonal trend at the upper flat with lowest rates during December 2001, intermediate during March, June, September 2002 and March 2004 and highest rates during the very warm July 2003 (Fig. 6). The maximum oxygen penetration depth was also 2.4 to $2.8 \mathrm{~cm}$ at the lower sand flat. The aOCR at the lower flat was higher during June 2002 and similar to the upper flat during September 2002 (Fig. 6B).

The conservative minimum value for depthintegrated $\mathrm{SRR}_{\min }$ was obtained by integrating $\mathrm{pSRR}$ over the anoxic sediment depth down to $15 \mathrm{~cm}$. Thus, $\mathrm{SRR}_{\min }$ rates were inversely related to OCR with slightly lower rates during inundation than during exposure

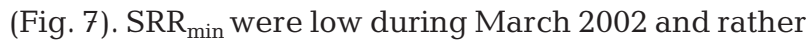
constant during all other months. The depth-integrated SRR at the upper and lower flats were similar.

Daily rates of areal oxygen consumption and depthintegrated sulfate reduction for all investigated months are presented for a full day and for exposure and inundation periods in Table 2. A significant linear relationship was found between mean temperature and daily aOCR at the upper sand flat $\left(\mathrm{p}<0.05, \mathrm{r}^{2}=0.68\right)$. The relationship between mean temperature and daily $\mathrm{SRR}_{\min } / \mathrm{SRR}_{\text {max }}$, however, was not significant, due to the relatively high sulfate reduction during December. Daily oxygen consumption rates at the lower sand flat were 2.8 times higher during June 2002 as compared to the upper flat as a result of the higher volumetric OCR 


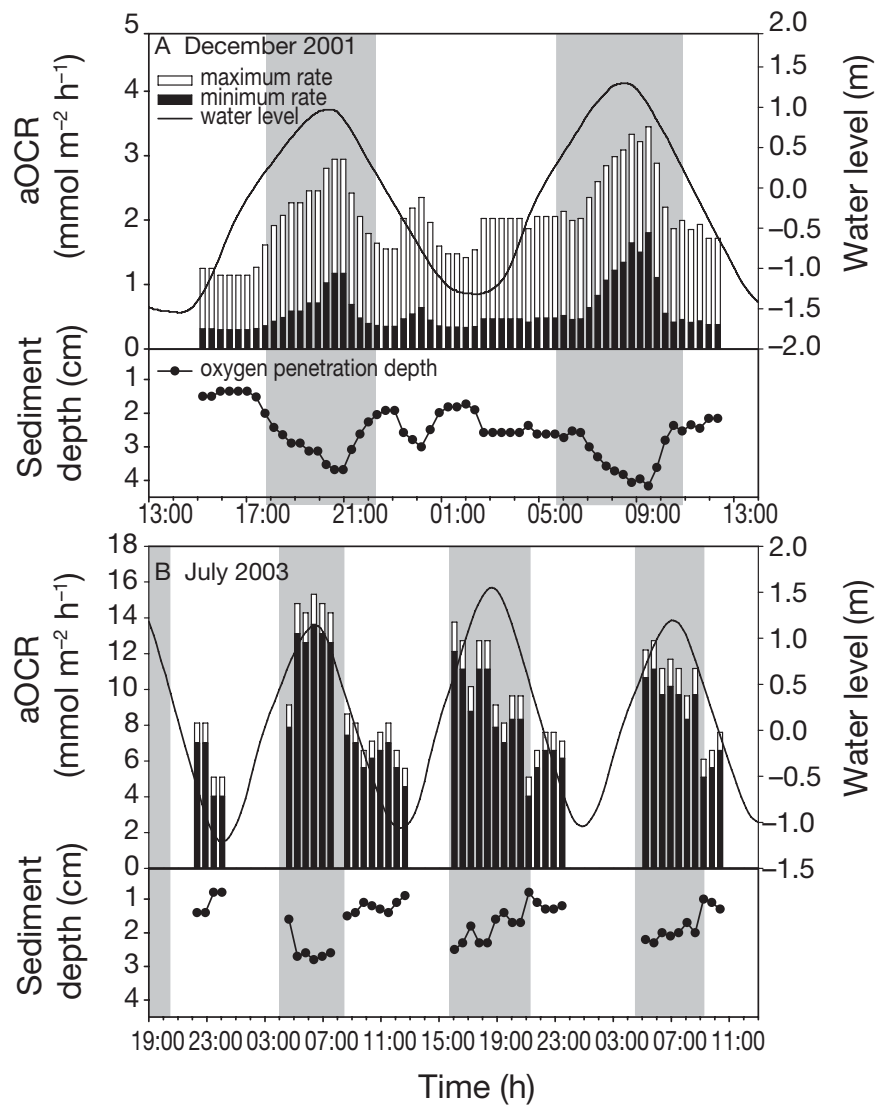

Fig. 5. Areal oxygen consumption rates (aOCR), seawater level and oxygen penetration depth over several tidal cycles during (A) December 2001 and (B) July 2003 (note different scalings for aOCR). Rates are given as minimum and maximum of 2 replicate pOCR measurements ( 3 replicates in July 2003). December rates were calculated from oxygen penetration measured in December 2001 and potential OCR (pOCR) measured in December 2002. White areas: periods of exposure; grey areas: periods of inundation

rates, but did not differ between the 2 sites during September 2002 (Table 2, Fig. 2). During average tidal cycles with about $14 \mathrm{~h}$ of exposure per day, daily OCR were approximately the same during exposure and inundation (Table 2), but this ratio shifted corresponding to longer inundation (September 2002) or exposure periods (March 2004). Daily SRR were only slightly higher at the lower sand flat site. Assuming that sulfate reduction was the dominant anaerobic mineralization process, sulfate reduction contributed between 3 and $25 \%$ to total mineralization (aOCR), depending on the season (Table 2).

\section{Pore water solute concentrations}

The pore water nutrient and DIC concentrations were one order of magnitude higher at the lower sand flat than at the upper flat during most months (Fig. 8).

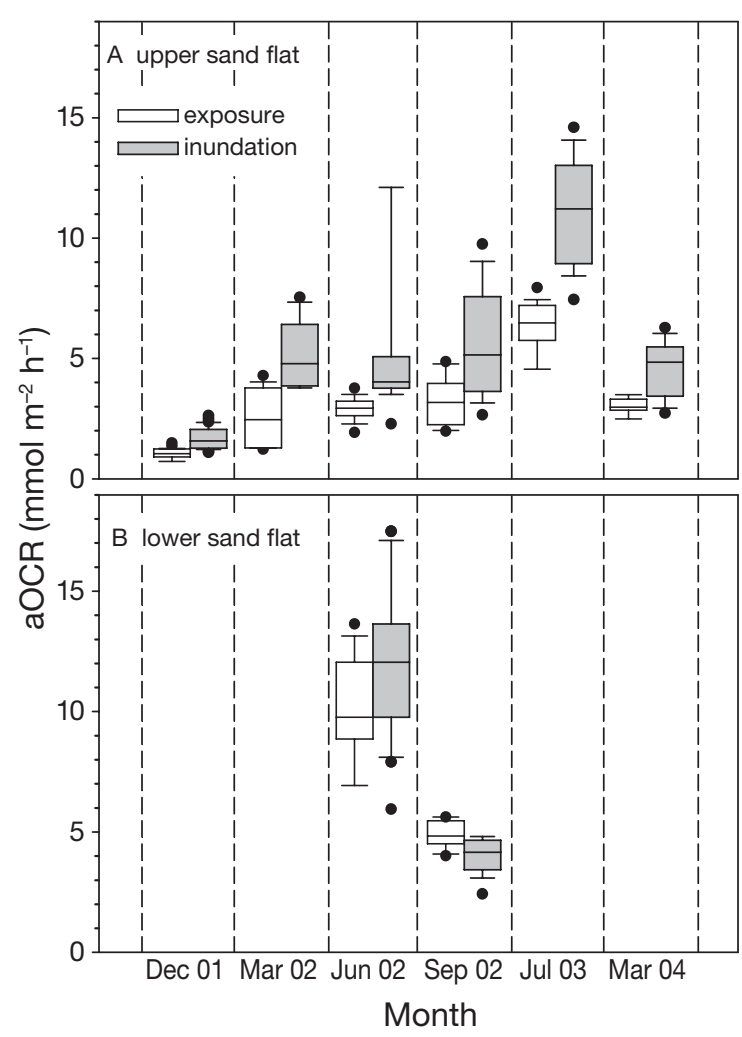

Fig. 6. Areal oxygen consumption rates (aOCR) during exposure (white boxes) and inundation (grey boxes) at the (A) upper and (B) lower sand flats between December 2001 and March 2004. Boxes comprise the 25th and 75th percentiles and the line within the boxes represents the median. The 10th and 90th percentiles are represented by whiskers and outliers by filled circles

This difference was most distinct during December 2001 and from December 2002 until March 2004 ( p < 0.001 ) but less pronounced during June and September 2002 ( $\mathrm{p}<0.001, \mathrm{p}<0.01$ for silicate). Pore water DOC concentrations, on the other hand, never were different between both study sites.

At the upper sand flat, the solute concentrations (nutrients, DIC, DOC) showed a seasonal trend with higher concentrations during the warmer months (June, July, September) and lower concentrations during the colder months (March, December) $(p<0.001)$. Surprisingly, no seasonality was apparent for the lower sand flat, as nutrient and DIC concentrations were lower in summer 2002 than in winter 2002 and a further increase in concentrations was observed in summer 2003 and spring 2004.

The pore water solute concentrations varied only slightly between the tidal cycle samplings at the upper sand flat and no particular pattern could be observed. All upper sand flat profiles were regarded as replicates, as they did not differ significantly ( $p>0.05)$. 


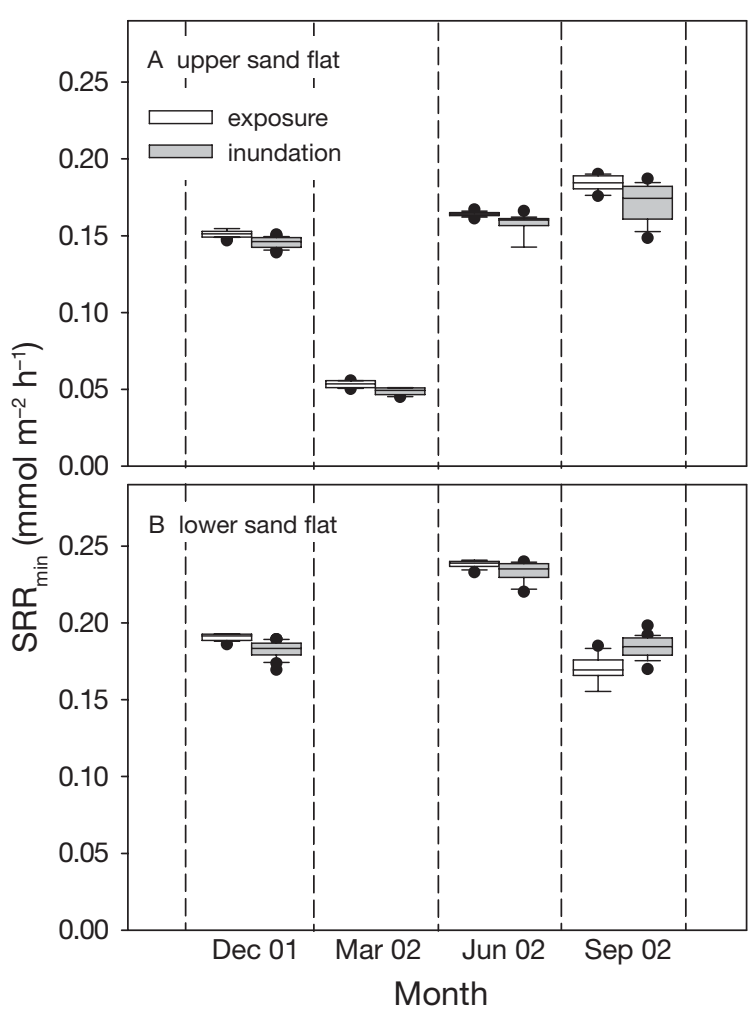

Fig. 7. Sulfate reduction rates integrated over the anoxic sediment down to $15 \mathrm{~cm}$ depth $\left(\mathrm{SRR}_{\min }\right)$ during exposure (white boxes) and inundation (grey boxes) at the (A) upper and (B) lower sand flat. Boxes comprise the 25 th and 75 th percentiles and the line within the boxes represents the median. The 10th and 90th percentiles are represented by whiskers and outliers by filled circles

\section{DISCUSSION}

\section{Variability of aOCR and depth-integrated SRR over the tidal cycle}

Oxygen generally penetrated deeper into the sediment during inundation of the Janssand tidal flat. The deeper oxygen penetration resulted in higher aOCR and lower SRR (minimum assessment) during submergence.

In laboratory measurements, Brotas et al. (1990) attributed a deeper oxygen penetration into exposed sandy sediment to intrusion of air, which was also postulated by Usui et al. (1998), based on the observation that the upper layer of an intertidal flat became undersaturated with water during exposure. Porosity measurements during July 2003 at the Janssand tidal flat, however, did not reveal a significant decrease in water content during low tide and the sediment remained fully saturated. In fine sands such as the Janssand tidal flat, capillary forces keep the sediment pores waterfilled (Drabsch et al. 1999, Atherton et al. 2001) pre- venting intrusion of air. Nevertheless, in situ oxygen penetration was much deeper (down to $15 \mathrm{~mm}$ in July 2003 and March 2004) than in retrieved laboratory cores ( 2 to $3.5 \mathrm{~mm}$ for July and March, respectively) kept in an aerated water bath at in situ temperature.

Although benthic photosynthesis can generate high oxygen concentrations in the surface layer of the sediment (Revsbech et al. 1980, Berninger \& Huettel 1997), at no time did we observe consistently deeper oxygen penetration and, hence, higher OCR during daylight exposure than during nighttime exposure (Fig. 5). Macrofauna can strongly enhance interfacial exchange processes (Rhoads 1974, Huettel 1990, Graf \& Rosenberg 1997), but faunal activity is heterogeneous and unlikely to cease completely during the laboratory measurements. Thus, other mechanisms were responsible for the deeper in situ penetration of oxygen during low tide than in the laboratory. We observed that during exposure the Janssand sand flat continuously drains pore water that flows through the sediment towards the low water line. This drainage permits intrusion of the oxygen-rich water that remained as puddles on the sediment surface into the sand and also penetration of oxygen contained in surface layer pore water deeper into the bed. Dispersion of the pore water flow within the porous sediment matrix may further enhance oxygen penetration depth. These mechanisms are not active in the retrieved cores, explaining the lesser oxygen penetration in the laboratory.

During inundation of the tidal flat, the interaction of unidirectional or oscillating water currents with sediment topography induces advective flow of pore water through the permeable bed (Webb \& Theodor 1968, Thibodeaux \& Boyle 1987, Huettel \& Gust 1992). Pressure oscillations caused by waves passing over the permeable sediment also contribute to the pore water flow (Riedl et al. 1972, van der Loeff 1981). Bottom currents and waves lead to a continuous change of sediment topography, e.g. by ripple migration. Oscillating flow interacting with sediment ripples generates an intrusion of oxygenated water into the ripple faces and outflow of anoxic pore water near the ripple crests (Precht \& Huettel 2003). This leads to varying oxygen penetration depths at small spatial scales corresponding to the ripple length. Along with ripple migration during inundation, as observed in several oxygen profiles from the study site, the intrusion/outflow-zones move along the sediment surface (Precht et al. 2004, Franke et al. 2006). Additionally, the bioirrigation activity of benthic macrofauna during submergence can lead to a deeper transport of oxygen into the sediment (Aller 2001, Wenzhöfer \& Glud 2004). Benthic photosynthesis, on the other hand, may decrease with increasing water depth due to diminishing light penetration in the turbid Wadden Seawaters (Colijn \& Cadee 2003). 


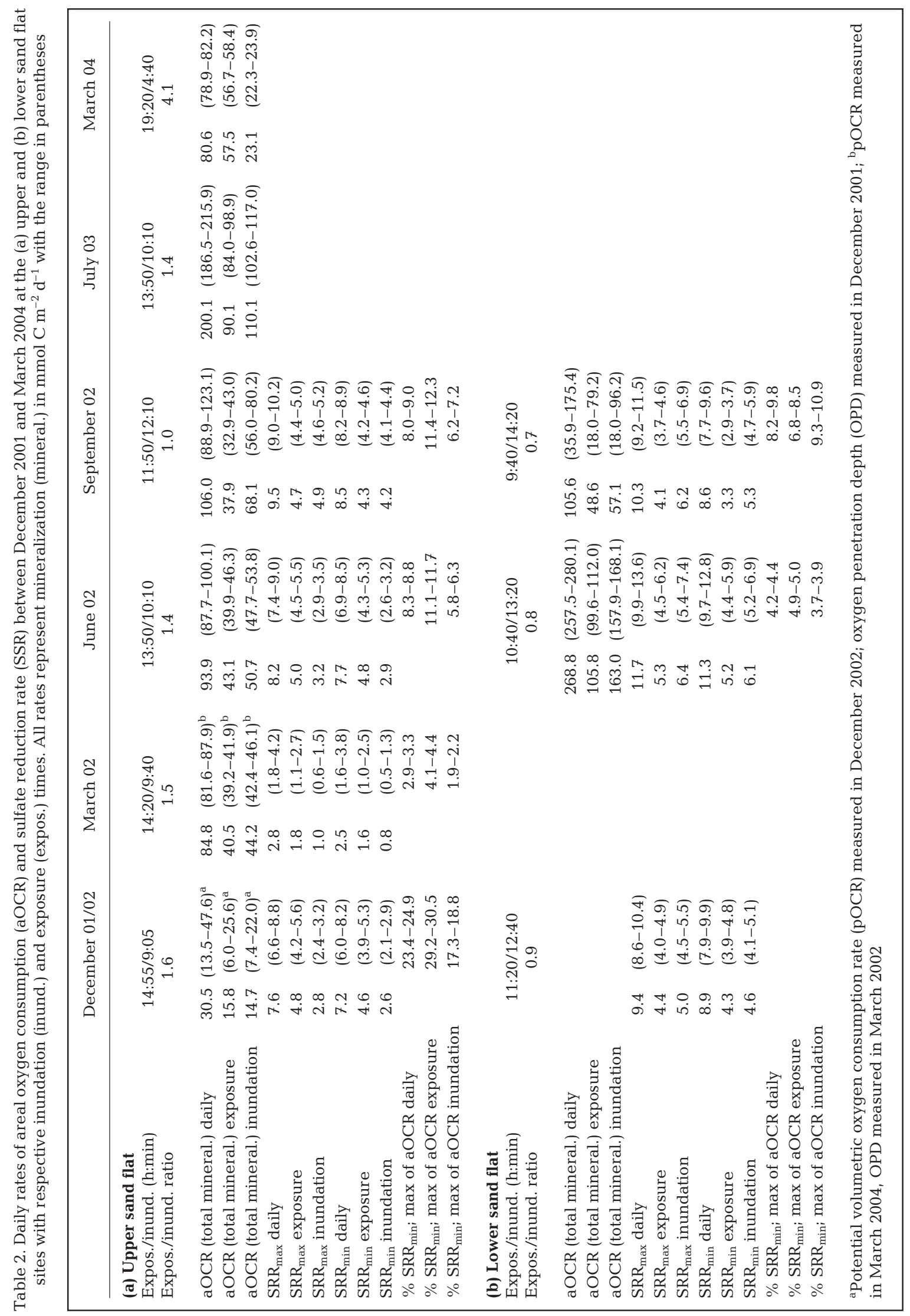




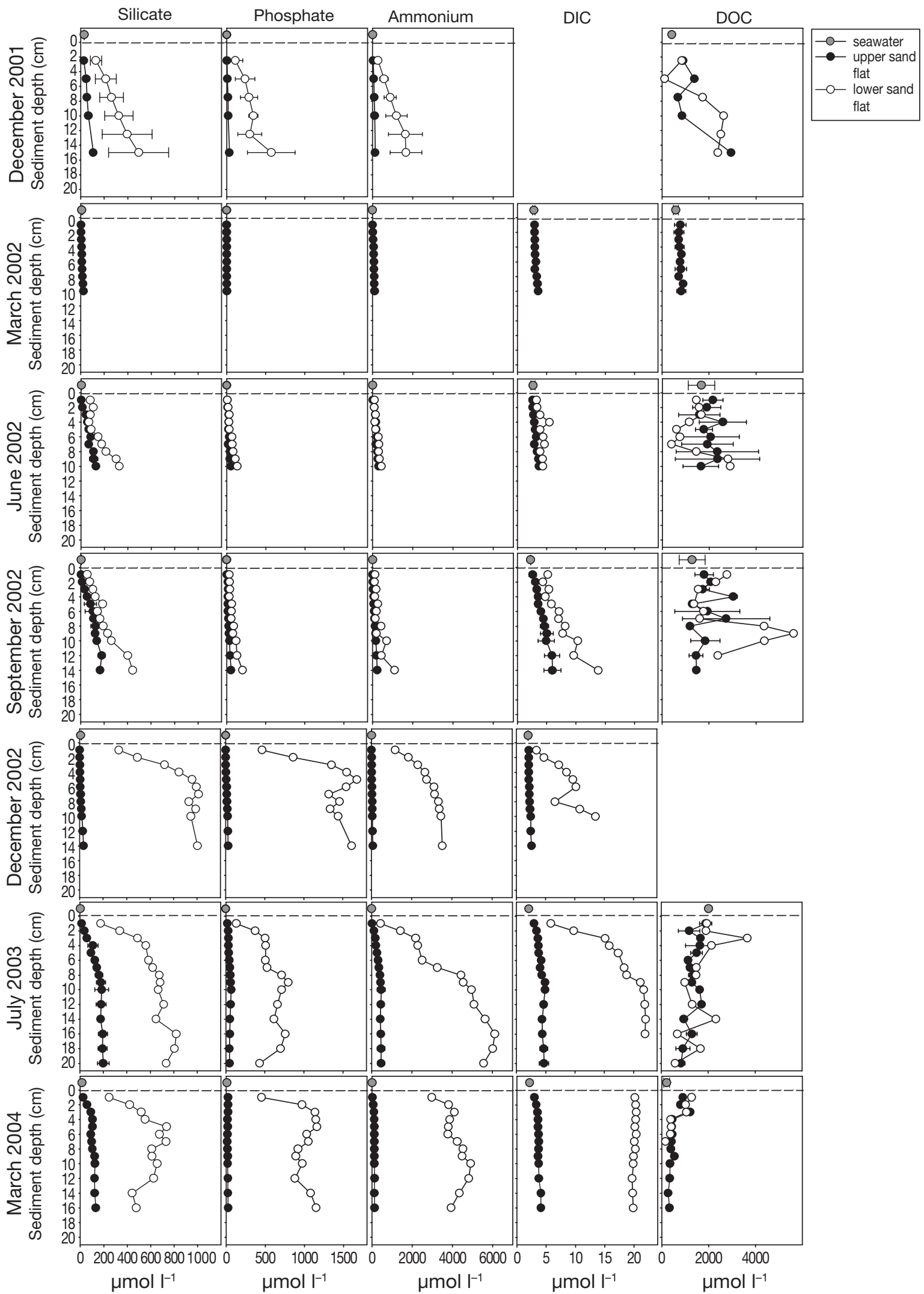

Fig. 8. Pore water nutrient, DIC and DOC concentrations at the upper and lower sand flat sites. No data are available for DIC (December 2001) and DOC (December 2002) 
Combined measurements of near bottom water flow and oxygen profiles at the Janssand tidal flat revealed a deeper oxygen penetration with increasing average flow velocities (Fig. 9) and the correlation between oxygen penetration depth (OPD) and flow velocity was significant $\left(p<0.005, r^{2}=0.68\right)$. Bottom current induced flushing of oxygenated water through the upper sediment layers, and thus, is responsible for the variability in OPD, the higher aOCR and lower depthintegrated SRR during inundation of the Janssand tidal flat. Observations of co-variance of bottom flow and oxygen penetration in a recent study of another intertidal sand flat (Werner et al. 2006) supports this conclusion.

The importance of advective pore water exchange and resulting oxygen supply to the sediment for the mineralization of organic matter is reflected by the pOCR that were at least one order of magnitude higher than the pSRR (compare Figs. 2 \& 4). Consequently, the share of depth-integrated sulfate reduction to total mineralization was relatively low in the investigated top $15 \mathrm{~cm}$ of the Janssand sediment (3 to $10 \%$ during most months). The microbial community can access the high-energy yield of aerobic mineralization as soon as oxygen is supplied to the respective sediment layers. Despite the enhancement of potential mineralization rates by the advective oxygen supply during submergence and the lower potential rates during exposure, total mineralization during low tide can be as high as during submergence due to the relatively long exposure of the Janssand during an average tidal cycle. This may also partially explain why no tidal differences in pore water nutrient and DIC concentrations were measured. Tidal differences in pore water nutrients and DIC were not evident even during extraordinarily long (September 2002) and short (March 2004) inundation periods. Possible pore water concentration

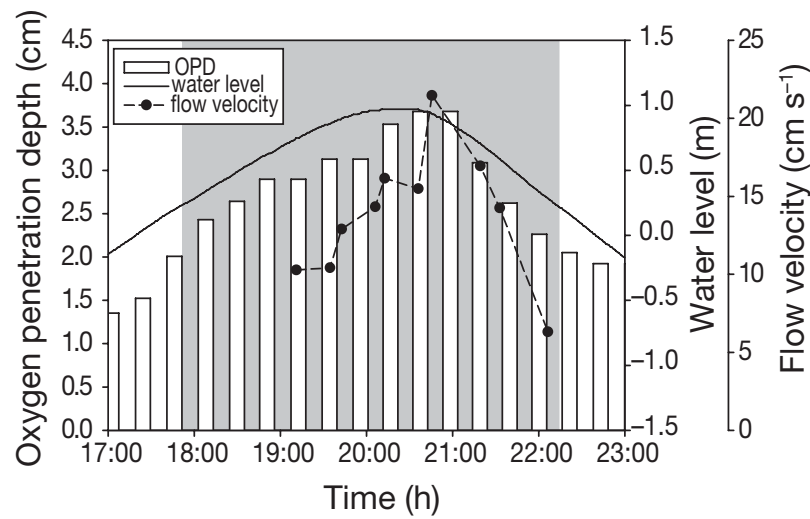

Fig. 9. Relationship between the average water flow velocity $5 \mathrm{~cm}$ above the sea floor and oxygen penetration depth (OPD) during December 2001. Solid line denotes the change of the seawater level relative to mean sea level. White areas: periods of exposure; grey areas: periods of inundation differences were probably too small within this short timeframe and may have been masked by spatial heterogeneity or by adsorption/desorption reactions within the sediment (Mackin \& Aller 1984, van Raaphorst \& Kloosterhuis 1994).

\section{Seasonal variability of OCR and SRR}

The OCR were consistent with the temperature dependence of aerobic mineralization (Thamdrup et al. 1998), and a higher availability and degradability of organic matter during the summer months may have contributed to the observed seasonality of oxygen consumption. For sulfate reduction, seasonality was only partially evident with the low March values, but December rates were close to the summer values. This is surprising, as the temperature dependence for sulfate reduction is even stronger than that of aerobic mineralization (Thamdrup et al. 1998). In September 2002, high rates of sulfate reduction in the uppermost sediment layers of both study sites suggest a recent input of fresh organic matter, possibly by an autumn algal bloom. In December 2001, the sulfate reducers possibly profited from the mineralization of such an algal bloom as reflected in only slightly lower pore water DOC concentrations in winter as compared to June and September 2002 (see Fig. 8).

\section{Differences between the upper and lower sand flat sites}

Higher mineralization rates should lead to increased concentrations of degradation products such as DIC and nutrients. Indeed, the seasonal trend of oxygen consumption rates was reflected in the solute concentrations at the upper sand flat site. Interestingly, this was not the case for the lower sand flat, where nutrient and DIC concentrations were not linked to season. Depth-integrated sulfate reduction and aOCR were comparable between both study sites and thus cannot explain the observed 5 to 15 times higher concentrations of degradation products at the lower flat. Benthic chamber incubations confirmed the similar oxygen consumption rates for both study sites (Billerbeck et al. 2006) and comparable sulfate reduction rates between both sites were also measured in another study at this tidal flat (K. Bosselmann, Forschungs- und Technologiezentrum Westküste, Büsum pers. comm.). The higher oxygen consumption at the lower flat in June 2002 was restricted to a $1 \mathrm{~cm}$ thick sediment layer (see Fig. 2), suggesting the presence of buried organic material such as macroalgae and may reflect spatial variability. Nevertheless, the relatively low TOC con- 
tent of the sediment at both study sites during all seasons cannot explain the observed difference in pore water metabolic products. In order to produce the large difference in solute concentrations between the 2 sites observed in July 2003 and March 2004, mineralization rates (as estimated from aOCR) would need to be about 10 times higher at the lower flat. As this was clearly not the case, the high concentration of metabolic products and seasonal independence of these concentrations at the lower sand flat points to a nonlocal source for the nutrients and DIC at this site.

As the Janssand sediment has a permeability permitting pore water flow, the exposure of the tidal flat during low tide and ensuing hydraulic gradient between the pore water table and seawater level lead to drainage transport of pore water through the sediment from the upper flat directed towards the low water line (Nielsen 1990). Tracer injections revealed that this drainage affects at least the sediment layers down to $50 \mathrm{~cm}$ depth, with drainage transport velocities of 0.07 to $0.12 \mathrm{~m} \mathrm{~d}^{-1}$ (Billerbeck et al. 2006). Sedimentary decomposition processes and drainage transport result in a concentration increase of metabolic products towards the low water line. With the rather slow drainage transport, about 1 to 2 yr are needed for the pore water to travel the distance of $50 \mathrm{~m}$ from the upper flat to the lower flat. Due to mixing and dispersion within the sediment during this passage, seasonal fluctuations in concentrations of metabolic products are evened out and, thus, are absent at the point of emergence. Slow pore water flows likely exist also below $50 \mathrm{~cm}$ sediment depth with degradation products originating from the large inner zone of the tidal flat. Such deep flows may additionally contribute to the high pore water solute concentrations at the lower flat sampling site.

In contrast to nutrients and DIC, DOC concentrations followed a seasonal trend at the lower flat, similar to the situation at the upper flat. We explain this observation with the different transport characteristics of dissolved and particulate material in the sand (Huettel et al. 1996) and the close link between particulate and dissolved organic matter concentrations observed in marine sediments (Ehrenhauss et al. 2004). Degradable organic particles, e.g. phytoplankton cells, are retained in the uppermost sediment layer in permeable sediment when water is filtered through the bed due to drainage or bottom current driven sediment percolation (Pilditch et al. 1997, Huettel \& Rusch 2000). The degradation of this material may only cause a nonsignificant change in the nutrient concentration at the lower flat site due to the relatively high background concentrations; however, it may have caused the noticeable seasonal changes in the DOC concentration at that site and also at the upper flat site.

At the lower sand flat, drained pore water is discharged via the sediment surface from a seepage face that extends from the low water line about $30 \mathrm{~m}$ upslope the tidal flat. As a consequence of this discharge, reduced substances are highly concentrated also in the upper sediment layer of the seepage face that is regularly flushed with seawater during inundation. The contribution of chemical oxidation to measurements of total oxygen consumption in the regularly oxygenated sediment layer of the lower flat needs to carefully be accounted for, especially during periods with high concentration of reduced substances at this site. This was evident in the September 2002 measurement of pOCR at the lower flat, where the repeated flushing of the sediment resulted in a distinct decrease in oxygen consumption. Probably, the rates measured after flushing the large pool of reduced substances out of the sediment may best represent the actual aerobic mineralization. At the upper sand flat, the contribution of chemical oxidation to total oxygen consumption is likely small in the regularly oxygenated sediment layer (Polerecky et al. 2005).

Our results demonstrate that the nutrient recycling by the filtration system sand flat works on 2 distinctly different temporal and spatial scales depending on tidal phase (Fig. 10):

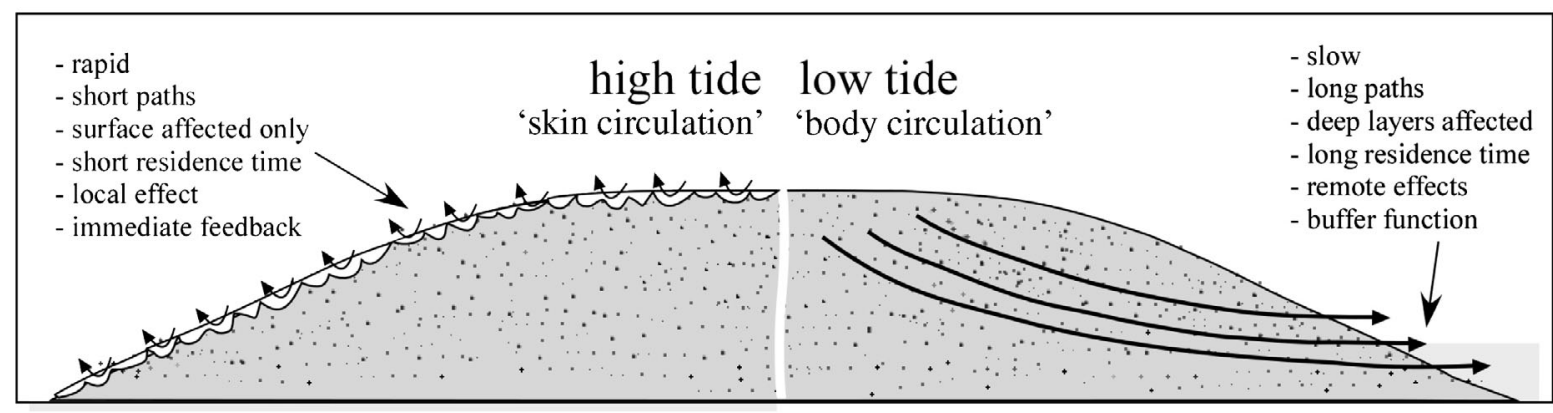

Fig. 10. 'Skin' and 'body' circulation in an intertidal sand flat. During inundation, boundary flow-topography interaction causes flushing of the surface sediment layer. Organic particles are filtered from the water, degraded and nutrients are returned promptly. During exposure, drainage removes nutrient-rich pore water from the entire sand flat, providing a season-independent nutrient source which acts as a buffer 
(1) 'Skin circulation', the filtration of water through the surface layer of the sediment caused by bottom flow-topography interaction during the inundation period. This process flushes the upper few centimeters of the sand bed, resulting in retention of degradable organic particles in the surface layer and flushing of metabolic products (inorganic nutrients, DIC) from this layer. The spatial scale of these 'skin circulation cells' is in the order of centimeters and the time scale is in the order of minutes to hours. Based on the measured OPD and pore water solute profiles, an approximately $5 \mathrm{~cm}$ thick layer at the sediment surface is affected by the skin circulation during periods of average currents and waves $\left(10\right.$ to $50 \mathrm{~cm} \mathrm{~s}^{-1}$ flow velocities at $10 \mathrm{~cm}$ above the bed). For such settings and sediments with similar permeabilities, laboratory measurements suggest filtration rates of 50 to $100 \mathrm{l} \mathrm{m}^{-2} \mathrm{~d}^{-1}$ (Huettel \& Gust 1992, Precht \& Huettel 2003). This would result in a filtration of 4600000 to $9200000 \mathrm{l} \mathrm{d}^{-1}$ during $9 \mathrm{~h}$ average daily inundation when extrapolated to $245000 \mathrm{~m}^{2}$ of the Janssand margin that is influenced by infiltration and discharge. Solute concentrations in these small and rapid circulation cells reflect tidal, daily and seasonal patterns. The recycling of nutrients of the small cells, thus, provides immediate feedback to the ecosystem during inundation.

(2) 'Body circulation', the filtration of water through the sand flat due to drainage of a thick sediment layer (>50 cm) during exposure. This 'body circulation cell' filters a large water volume (total discharge from the Janssand margin about 170000 to $300000 \mathrm{l} \mathrm{d}^{-1}$, Billerbeck et al. 2006) through the body of the sand flat at a relatively small pore flow velocity. Since the spatial scales of this large flow cell are in the order of tens to hundreds of meters, the residence time is rather long with time scales in the order of years to tens of years. This recycling, thus, is independent of seasonal oscillations and can act as a nutrient reservoir and nutrient source during times of low nutrient concentrations in the water column.

With the combination of a fast and a slow nutrient recycling system, the tidal sand filter rapidly responds to organic matter input by instantaneous nutrient regeneration and release, while at the same time the sand flat acts as a buffer for nutrients that is independent of short-term and seasonal fluctuations. The rapid 'skin circulation' feeds back nutrients only during inundation and thus supports benthic and pelagic primary production within the intertidal area. 'Skin circulation' potentially filters about 15 to 50 times more water through the Janssand sediments as the 'body circulation'; thus, it may be more significant for sedimentary metabolism, the cycling of matter and nutrient remobilization in the intertidal sands. However, the 'body circulation' carries electron acceptors and dissolved organic matter into and through the deeper sediment layers and thus, tightly couples the decomposition processes in the deeper sediments to the production processes at the surface. The 'body circulation' returns nutrients only during exposure of the tidal flat and contributes to the increase in nutrient concentration of the Wadden Seawater during low tide (Niesel \& Günther 1999). The export of this nutrient rich water by tidal currents and a decreased turbidity in the open North Sea can lead to high primary production in a belt of coastal waters seaward of the barrier islands (Colijn et al. 1987, Colijn \& Cadee 2003). The ecological consequence of such a recycling system operating on 2 different alternating time scales is a dampening of short-term and seasonal fluctuations in primary productivity through immediate feed back as well as continuous nutrient return to the system. Because the slow 'body circulation' releases pore water only during low tide, this process may act also as an efficient pump that removes metabolic products from the intertidal zone to the North Sea with the tidal currents. This removal may be essential for maintaining the function of the intertidal sands as sites of efficient organic matter turnover.

Acknowledgements. We thank M. Alisch for the assistance with field and laboratory work and acknowledge the hospitality and help of the Plattboden ship crews during the cruises. We thank G. Schüßler, S. Menger, D. Franzke and S. Pabel for their help with laboratory work. We acknowledge G. Eickert, I. Schröder, K. Hohman, I. Dohrmann and C. Wiegand for making the sensors and thank J. Langreder, A. Nordhausen, G. Herz, A. Kutsche, P. Färber, V. Meyer and H. Osmers for technical assistance. W. Anton of the WSA Emden kindly provided tide gauge data. The comments of 3 anonymous referees greatly helped to improve this manuscript. This study was supported by the Deutsche Forschungsgemeinschaft (DFG) within the research group 'Biogeochemistry of the Wadden Sea' (FG 432-5), coordinated by Prof. J. Rullkötter. We are grateful to Prof. B. B. Jørgensen and Dr. M. E. Böttcher for their support of this work and coordination of the sub-project 'Biogeochemical processes at the sediment-water interface of intertidal sediments'.

\section{LITERATURE CITED}

Aller RC (2001) Transport and reactions in the bioirrigated zone. In: Boudreau BP, Jørgensen BB (eds) The benthic boundary layer. Oxford University Press, Oxford, p 269-301

Atherton RJ, Baird AJ, Wiggs GFS (2001) Inter-tidal dynamics of surface moisture content on a meso-tidal beach. J Coast Res 17:482-489

Bergamaschi BA, Tsamakis E, Keil RG, Eglinton TI, Montlucon DB, Hedges JI (1997) The effect of grain size and surface area on organic matter, lignin and carbohydrate concentration, and molecular compositions in Peru Margin sediments. Geochim Cosmochim Acta 61:1247-1260

Berninger UG, Huettel M (1997) Impact of flow on oxygen dynamics in photosynthetically active sediments. Aquat Microb Ecol 12:291-302 
Billerbeck M, Werner U, Bosselmann K, Walpersdorf E, Huettel M (2006) Nutrient release from an exposed intertidal sand flat. Mar Ecol Prog Ser 316:35-51

Boudreau B, Huettel M, Forster R, Jahnke A and 10 others (2001) Permeable marine sediments: overturning an old paradigm. EOS Trans Am Geophys Union 82:133-136

Brotas V, Amorim-Ferreira A, Vale C, Catarino F (1990) Oxygen profiles in intertidal sediments of Ria Formosa (S. Portugal). Hydrobiologia 207:123-129

Cammen LM (1991) Annual bacterial production in relation to benthic microalgal production and sediment oxygenuptake in an intertidal sandflat and an intertidal mudflat. Mar Ecol Prog Ser 71:13-25

Colijn F, Cadee GC (2003) Is phytoplankton growth in the Wadden Sea light or nitrogen limited? J Sea Res 49:83-93

Colijn F, Admiraal W, Baretta JW, Ruardij P (1987) Primary production in a turbid estuary, the Ems-Dollard: field and model studies. Cont Shelf Res 7:1405-1409

D'Andrea AF, Aller RC, Lopez GR (2002) Organic matter flux and reactivity on a South Carolina sandflat: the impacts of pore water advection and macrobiological structures. Limnol Oceanogr 47:1056-1070

Dauwe B, Middelburg JJ, Herman PMJ (2001) Effect of oxygen on the degradability of organic matter in subtidal and intertidal sediments of the North Sea area. Mar Ecol Prog Ser 215:13-22

de Beer D, Wenzhoefer F, Ferdelman TG, Boehme SE and 5 others (2005) Transport and mineralization rates in North Sea sandy intertidal sediments, Sylt-Rømø basin, Wadden Sea. Limnol Oceanogr 50:113-127

Drabsch JM, Parnell KE, Hume TM, Dolphin TJ (1999) The capillary fringe and the water table in an intertidal estuarine sand flat. Estuar Coast Shelf Sci 48:215-222

Ehrenhauss S, Witte U, Bühring SL, Huettel M (2004) Effect of advective pore water transport on distribution and degradation of diatoms in permeable North Sea sediments. Mar Ecol Prog Ser 271:99-111

Flemming BW, Ziegler K (1995) High-resolution grain size distribution patterns and textural trends in the backbarrier environment of Spiekeroog island (southern North Sea). Senckenb Marit 26:1-24

Forster S, Huettel M, Ziebis W (1996) Impact of boundary layer flow velocity on oxygen utilisation in coastal sediments. Mar Ecol Prog Ser 143:173-185

Fossing H, Jørgensen BB (1989) Measurement of bacterial sulfate reduction in sediments - evaluation of a singlestep chromium reduction method. Biogeochemistry 8: 205-222

Franke U, Polerecky L, Precht E, Huettel M (2006) Wave tank study of particulate organic matter degradation in permeable sediments. Limnol Oceanogr 51:1084-1096

Glud RN, Forster S, Huettel M (1996) Influence of radial pressure gradients on solute exchange in stirred benthic chambers. Mar Ecol Prog Ser 141:303-311

Glud RN, Klimant I, Holst G, Kohls O, Meyer V, Kuhl M, Gundersen JK (1999) Adaptation, test and in situ measurements with $\mathrm{O}_{2}$ microopt(r)odes on benthic landers. DeepSea Res I 46:171-183

Graf G, Rosenberg R (1997) Bioresuspension and biodeposition: a review. J Mar Syst 11:269-278

Grasshoff K, Kremling K, Ehrhardt M (1999) Methods of seawater analysis. Wiley-VCH Verlag, Weinheim

Hall POJ, Aller RC (1992) Rapid, small-volume, flow injection analysis for $\sigma \mathrm{CO}_{2}$ and $\mathrm{NH}_{4}^{+}$in marine and freshwaters. Limnol Oceanogr 37:1113-1119

Howes BL, Goehringer DD (1994) Pore water drainage and dissolved organic carbon and nutrient losses through the intertidal creekbanks of a New England salt marsh. Mar Ecol Prog Ser 114:289-301

Huettel M (1990) Influence of the lugworm Arenicola marina on pore water nutrient profiles of sand flat sediments. Mar Ecol Prog Ser 62:241-248

Huettel M, Gust G (1992) Impact of bioroughness on interfacial solute exchange in permeable sediments. Mar Ecol Prog Ser 89:253-267

Huettel M, Rusch A (2000) Transport and degradation of phytoplankton in permeable sediment. Limnol Oceanogr 45:534-549

Huettel M, Webster IT (2001) Pore water flow in permeable sediments. In: Boudreau B P, Jørgensen BB (eds) The benthic boundary layer. Oxford University Press, Oxford, p 144-179

Huettel M, Ziebis W, Forster S (1996) Flow-induced uptake of particulate matter in permeable sediments. Limnol Oceanogr 41:309-322

Huettel M, Ziebis W, Forster S, Luther GW (1998) Advective transport affecting metal and nutrient distributions and interfacial fluxes in permeable sediments. Geochim Cosmochim Acta 62:613-631

Huettel M, Røy H, Precht E, Ehrenhauss S (2003) Hydrodynamical impact on biogeochemical processes in aquatic sediments. Hydrobiologia 494:231-236

Jahnke RA, Alexander CR, Kostka JE (2003) Advective pore water input of nutrients to the Satilla river estuary, Georgia, USA. Estuar Coast Shelf Sci 56:641-653

Jørgensen BB (1977) Bacterial sulfate reduction within reduced microniches of oxidized marine-sediments. Mar Biol 41:7-17

Jørgensen BB (1978) Comparison of methods for the quantification of bacterial sulfate reduction in coastal marinesediments. 1. Measurement with radiotracer techniques. Geomicrobiol J 1:11-27

Jørgensen BB (1982) Mineralization of organic-matter in the sea bed - the role of sulfate reduction. Nature 296:643-645

Jørgensen BB, Bak F (1991) Pathways and microbiology of thiosulfate transformations and sulfate reduction in a marine sediment (Kattegat, Denmark). Appl Environ Microbiol 57:847-856

Kallmeyer J, Ferdelman TG, Weber A, Fossing H, Jørgensen BB (2004) A cold chromium distillation procedure for radiolabeled sulfide applied to sulfate reduction measurements. Limnol Oceanogr: Methods 2:171-180

Klute A, Dirksen C (1986) Hydraulic conductivity and diffusivity: laboratory methods. In: Klute A (ed) Methods of soil analysis, Part 1. Physical and mineralogical methods. American Society of Agronomy, Madison, WI, p 687-700

Kuwae T, Kibe E, Nakamura Y (2003) Effect of emersion and immersion on the pore water nutrient dynamics of an intertidal sandflat in Tokyo bay. Estuar Coast Shelf Sci 57:929-940

Llobet-Brossa E, Rossello-Mora R, Amann R (1998) Microbial community composition of Wadden Sea sediments as revealed by flourescence in situ hybridization. Appl Environ Microbiol 64:2691-2696

Lohse L, Epping EHG, Helder W, van Raaphorst W (1996) Oxygen pore water profiles in continental shelf sediments of the North Sea: turbulent versus molecular diffusion. Mar Ecol Prog Ser 145:63-75

Mackin JE, Aller RC (1984) Ammonium adsorption in marine sediments. Limnol Oceanogr 29:250-257

Marschall C, Frenzel P, Cypionka H (1993) Influence of oxygen on sulfate reduction and growth of sulfate-reducing bacteria. Arch Microbiol 159:168-173

Nielsen P (1990) Tidal dynamics of the water table in beaches. Water Resour Res 26:2127-2134 
Niesel V, Günther CP (1999) Distribution of nutrients, algae and zooplankton in the Spiekeroog backbarrier system. In: Dittmann S (ed) The Wadden Sea ecosystem - stability properties and mechanisms. Springer-Verlag, Berlin, p 77-94

Orvain F, Sauriau PG (2002) Environmental and behavioural factors affecting activity in the intertidal gastropod Hydrobia ulvae. J Exp Mar Biol Ecol 272:191-216

Pilditch CA, Emerson CW, Grant J (1997) Effect of scallop shells and sediment grain size on phytoplankton flux to the bed. Cont Shelf Res 17:1869-1885

Polerecky L, Franke U, Werner U, Grunwald B, de Beer D (2005) High spatial resolution measurement of oxygen consumption rates in permeable sediments. Limnol Oceanogr: Methods 3:75-85

Precht E, Huettel M (2003) Advective pore-water exchange driven by surface gravity waves and its ecological implications. Limnol Oceanogr 48:1674-1684

Precht E, Franke U, Polerecky L, Huettel M (2004) Oxygen dynamics in permeable sediments with wave-driven pore water exchange. Limnol Oceanogr 49:693-705

Revsbech NP (1989) An oxygen microsensor with a guard cathode. Limnol Oceanogr 34:474-478

Revsbech NP, Sørensen J, Blackburn TH, Lomholt JP (1980) Distribution of oxygen in marine sediments measured with microelectrodes. Limnol Oceanogr 25:403-411

Rhoads DC (1974) Organism-sediment relations on the muddy sea floor. Oceanogr Mar Biol Annu Rev 12:263-300

Riedl RJ, Huang N, Machan R (1972) The subtidal pump: mechanism of interstitial water exchange by wave action. Mar Biol 13:210-221

Rocha C (1998) Rhythmic ammonium regeneration and flushing in intertidal sediments of the Sado estuary. Limnol Oceanogr 43:823-831

Rusch A, Forster S, Huettel M (2001) Bacteria, diatoms and detritus in an intertidal sandflat subject to advective transport across the water-sediment interface. Biogeochemistry 55:1-27

Editorial responsibility: Otto Kinne (Editor-in-Chief), Oldendorf/Luhe, Germany
Rusch A, Huettel M, Reimers CE, Taghon GL, Fuller CM (2003) Activity and distribution of bacterial populations in Middle Atlantic Bight shelf sands. FEMS Microbiol Ecol 44:89-100

Thamdrup B, Hansen JW, Jørgensen BB (1998) Temperature dependence of aerobic respiration in a coastal sediment. FEMS Microbiol Ecol 25:189-200

Thibodeaux LJ, Boyle JD (1987) Bedform-generated convective transport in bottom sediment. Nature 325:341-343

Usui T, Koike I, Ogura N (1998) Tidal effect on dynamics of pore water nitrate in intertidal sediment of a eutrophic estuary. J Oceanogr 54:205-216

van der Loeff MMR (1981) Wave effects on sediment water exchange in a submerged sand bed. Neth J Sea Res 15: 100-112

van Raaphorst W, Kloosterhuis HT (1994) Phosphate sorption in superficial intertidal sediments. Mar Chem 48:1-16

Webb JE, Theodor J (1968) Irrigation of submerged marine sands through wave action. Nature 220:682-683

Wentworth CK (1922) A scale of grade and class terms for clastic sediments. J Geol 30:377-392

Wenzhöfer F, Glud RN (2004) Small-scale spatial and temporal variability in coastal benthic $\mathrm{O}_{2}$ dynamics: effects of fauna activity. Limnol Oceanogr 49:1471-1481

Wenzhöfer F, Holby O, Glud RN, Nielsen HK, Gundersen JK (2000) In situ microsensor studies of a shallow water hydrothermal vent at Milos, Greece. Mar Chem 69: 43-54

Werner U, Billerbeck M, Polerecky L, Franke U, Huettel M, van Beusekom JEE, de Beer D (2006) Spatial and temporal pattern of mineralization rates and oxygen distribution in a permeable intertidal sandflat (Sylt, Germany). Limnol Oceanogr 51:2549-2563

Whiting GJ, Childers DL (1989) Subtidal advective water flux as a potentially important nutrient input to southeastern USA saltmarsh estuaries. Estuar Coast Shelf Sci 28: $417-431$

Submitted: August 8, 2005; Accepted: March 31, 2006

Proofs received from author(s): October 15, 2006 